\title{
SNED1 wt Allele
}

National Cancer Institute

\section{Source}

National Cancer Institute. SNED1 wt Allele. NCI Thesaurus. Code C88945.

Human SNED1 wild-type allele is located in the vicinity of 2 q37.3 and is approximately 95 $\mathrm{kb}$ in length. This allele, which encodes sushi, nidogen and EGF-like domain-containing protein 1 , may play a role in the modulation of mesenchymal differentiation. 